\title{
Social Media Influencer Advertising versus Advertising on Social Media Account of a Brand. Evidence from an Experimental Design
}

\author{
Prof. Delia Cristina BALABAN, PhD \\ Department for Communication, PR, and Advertising \\ Faculty for Political, Administrative and Communication Science \\ Babeș-Bolyai University, Cluj-Napoca, Romania \\ Email: balaban@fspac.ro
}

\section{Roberta Gabriela RACZ \\ Department for Communication, PR, and Advertising \\ Faculty for Political, Administrative and Communication Science \\ Babeș-Bolyai University, Cluj-Napoca, Romania \\ Email: roberta_racz@yahoo.com}

\begin{abstract}
Nowadays, the relevance of advertising on social media is essential, especially for the young audience category for which traditional media is no longer a real consumer option. This paper aims to explore the differences in the efficiency of online advertising with and without the support of a social media influencer. We conducted a two-level survey-based online between subjects experiment and we manipulate advertising on an influencer account versus advertising on a brand account on social media without the support of the influencer. We compared the effects of the posts promoting Pantene shampoo on the Instagram account of a relevant Romanian beauty influencer Ioana Grama (335K followers) and the posts promoting the same product from the brand Romanian Instagram account (5K). The online survey was disseminated between April 4, 2020-May 7, 2020 , to a young female population $N=80$ participants, age 16 to 32 years,
\end{abstract}


that were randomly assigned in the two above mentioned groups. The stimulus included real posts in the questionnaire consisted of: Instagram posts of the Pantene Romania account for the "brand account" group and posts of the Romanian beauty influencer Ioana Grama for the "influencer" group. Results showed that advertising on influencer account is more efficient than advertising on the brand account regarding the effects on brand attitude.

Keywords: Social media influencer; Advertising; Social media advertising; Instagram, Experiment; Source effectiveness.

\section{Introduction}

The relevance of online communication for our society is constantly underlined by the media, by creative industries, and by researchers. The use of social media has become a common element of our daily life. With less interest in the young generation for traditional media such as TV and newspaper, advertising on social media has become more and more relevant for promoting the brand. To take advantage of the large-scale use of social media, the relatively low costs of campaigning in this particular virtual space almost every brand is present on at least one of the popular platforms such as Facebook, Instagram, YouTube, etc. (Voorveld, 2019). Brand communication in social media defined as brand-related communication „distributed via social media that enables internet users to access, share, engage with, add to, and co-create" (Alhabash, Mundel, \& Hussain 2017, 286) was also rapidly developed.

A process of differentiation of the promoting possibilities on social media has occurred during the last years. With the rapid development of technology, there are several options for brands to advertise their products online. Using their brand's accounts or using online social media content creators of influencers are just two of the common options. Advertising through influencers' social media accounts has rapidly developed worldwide (Voorveld, 2019) and Romania is no exception (Oprea, 2017). In the past consumers preferred to find out what's new directly in stores, technology has developed so much that consumers ended up finding out about new trends and then visiting online stores from the comfort of their homes by using few clicks. Social media celebrities contribute to the rapid dissemination of trends by creating content under a certain pattern that is meant to reach a very well-defined target audience.

The present research addressed the issue of the effectiveness of the source in social media advertising. The main objective of the current research is to compare the effects of social media influencer advertising to advertising on brands' social media account on attitudinal and behavioral outcomes such as brand attitude, purchase intention, and intention to disseminate (eWOM) of the consumers. 


\section{Theoretical framework}

Social media was defined as "a group of Internet-based applications that build on the ideological and technological foundations of Web 2.0 and allow the creation and exchange of user-generated content" (Kaplan \& Haenlein, 2010, 61) and it has a network nature. Among all the social media platforms Instagram has rapidly developed since 2010, the year it was founded, having over 1 billion users in 2019 (Statista, 2019). In terms of private versus public access, Instagram accounts can be both, in terms of longevity of the messages Instagram is offering two possibilities: that of the posts that are long lasting on the feed and that of the Instagram stories that are available for views only 24 hours from the time of publishing. Yet, the majority of the studies concerning advertising on Instagram have focused on the effects of posts.

In Romania, 75\% of Internet users, are following at least one influencer. They use different social media platforms to target age groups Facebook and Youtube remain in the top positions, immediately followed by Instagram and Twitter. Regarding, blogs, an instrument used by influencers the average audience is between 25-39 years or 45-49 years, which makes marketing companies achieve their promotion goals (Oprea, 2017). On Instagram the audience can appreciate a post, this being the only and most common way to react. Users can also consider the repost option, but this is not a high speeded practice for the feed, but the Instagram stories. Users follow influencers on Instagram for inspiration, to be up to date with notes, and for relaxation or fun. Campaigns that collaborate with influencers on Instagram determine those who follow them to look for more information about the product or brand promoted both online and offline, convince internet users to look for the product in stores, and try it at home.

Using Instagram, it is a consumer-friendly experience. From the first moments after logging in, on the news feed, users come across several forms of advertising with or without disclosure. It can be the account of a brand that is performing social media marketing, or the post of a celebrity endorsing products in the form of native advertising or even a post from peer using a brand. Social media advertising has become affordable and it has been simplified in such a way that it is accessible for both users and brands. Therefore, it is important to explore the effects of these promoting methods (Johnson et al., 2019). The advertising tool called influencer marketing entered the market some years ago. This type of marketing is one of the main channels for distributing information online with the central idea of celebrity endorsement.

Social media influencers are online personalities with a large number of followers, across one or several social media platforms such as YouTube, Instagram, Snapchat or recently TikTok (Freberg et al., 2011; Lou \&Yuan, 2018; Versamis, 2018; Nirschl \& Steinberg, 2018; Balaban \& Mustățea, 2019). They are individuals who create social media content in exchange for compensation (Campbell \& Grimm, 2019). 
Previous literature emphasized the complex role of social media influencers not only as content creators and distributors but also as entrepreneurs (Carpenter Childers et al., 2018). Social media celebrities or influencers are very popular among young audiences (Boerman \& van Reijmersdal, 2020). They build a community of followers (De Veirman et al., 2017) where they can act as opinion leaders in the sense of the two steps or a multistep communication flow model (Katz \& Lazarsfeld, 1955; Liu, 2007).

Advertising on social media using influencers is closely related to and includes elements of the word of mouth marketing, social media marketing, and content marketing, but it is much more than these. Social media marketing, for example, means promoting from a brand account on social media (Nirschl \& Steinberg, 2018). Studies revealed that influencer marketing is also related to celebrity endorsement that is an advertising tool that has been highly used by advertising. Previous research developed from celebrity endorsement (Ohanian, 1990), but there is an additional element to celebrity endorsement that made influencer marketing so popular: the peer or similarity element. Some researchers underlined the role of similarity for the source credibility of influencers (Johnson et al., 2019; Balaban \& Mustățea, 2020), even stating that influencers have more in common to social media users than to celebrities or experts (Voorveld, 2019).

In the last years, substantial research was published on the effects of advertising disclosure on social media influencer advertising (Boerman et al., 2014), focussing on the role of parasocial interaction (Boerman \& van Reijmersdal, 2020) or the source credibility of social media influencers (Jung \& Heo, 2019). The majority of the studies used as a theoretical background the persuasion knowledge model (Friedstad \& Wright,1994). Results of experimental studies showed the negative effect of ad disclosure on attitudinal and behavioral outcomes (Janssen \& Fransen, 2019; Mayrhofer et al., 2020; Evans et al., 2017). The scale of the influencer audience played a relevant role in the effectiveness of advertising as the literature distinguished between nano-, micro-, macro-influencers (De Veirman et al., 2017). Recently, consumers proved to appreciate the value of advertising transparency with effects on the attitude towards the brand, the attitude towards the ad and, on purchase intention (Evans et al., 2019). There are only a few studies published on this topic about Romanian consumers (Balaban \& Mustățea, 2019).

Despite the form, brand communication on social media is in many cases a socalled tailored ad and is characterized by, blurred lines between brand communication and other content" (Voorveld, 2019, 5). In the article entitled Is That My Friend or an Advert? The Effectiveness of Instagram Native Advertisements Posing as Social Posts, Johnson et al. (2019) addressed the issue of comparing the effects of brand posts versus native advertising versus posts by peers on Instagram. The results of their experimental study suggest that there are no differences between native ads, a type of advertising that includes influencer marketing and traditional social media adds posted on the account of a brand when it comes to brand attitude. Significant 
differences were observed only between traditional social media adds native advertising on one side and Instagram posts of peers advertising for brands.

Based on McGuire's (1995) communication persuasion matrix the present study explores the effects of factors related to the source of communication. According to this model credibility, attractiveness and power are the two characteristics of the source that influence the effectiveness of a campaign. In addition to them, the source-audience similarity is a relevant element that substantially contributes to positive outcomes. Influencers have that element of similarity as one of their distinguished features. Taking that into consideration, we hypothesized:

H1. Social media influencer advertising leads to higher brand recognition than advertising on the social media account of the brand.

H2. Social media influencer advertising leads to a higher attitude towards the promoted brand than the social media account of the brand.

H3. Social media influencer advertising leads to a higher purchase intention than the social media account of the brand.

H4. Social media influencer advertising leads to a higher intention to disseminate online information (eWOM) than social media account of the brand.

\section{Study design and participants}

The purpose of the present research is to compare the effectiveness of social media influencer advertising and social media advertising from the brand account on attitudinal and behavioral outcomes. To achieve this, we conducted an online twolevel survey-based between subjects' experiment. We had two groups: the advertising through the influencer group that we called the "influencer group" and the social media without the support of the influencer, or the "brand account" group. We apply the survey online during April the $4^{\text {th }}, 2020$, and May the $7^{\text {th }}, 2020$. The participants were enrolled via social media and participated on the voluntary basis. The sample consist in $N=80$ female participants, age 16 to 32 years, randomly assigned in the two above mentioned groups. In terms of education, $7.5 \%$ of the participants are alumni of the secondary school, $44.5 \%$ have a high school degree, $33.8 \%$ have a BA degree, $11.3 \%$ have a master's degree and $2.5 \%$ have a Ph.D. degree. The stimulus materials included in the questionnaire consisted of the Instagram account overview followed by a post of Pantene Romania, promoting the Pantene Shampoo for the "brand account" group and an account overview follow by a post of Ioana Grama, a Romanian well-known beauty influencer (335K) promoting the same product for the "influencer group". The participants received the indication to look at the posts like they usually do when they use Instagram. The posts were prior to our study posted on Instagram and the layout of the stimuli was suggesting to the participants that they are actually on the platform. These contributed to the external validity of the experiment (Stimulus materials in the appendix). 


\section{Measurements}

The dependent variables are:

To measure brand recall participants were asked to name the brand that was shown in the stimuli. The variable was coded with 1 for Pantene and 0 for no brand mention or wrong brand mention.

Brand attitude was measured using 7-point semantic differential scales with the adjectives 'unattractive-attractive', 'negative-positive'; 'boring-interesting', 'unlikeable-likeable' $(\alpha=.984, M=5.42, S D=1.47$; Matthes \& Naderer 2016).

Purchase intention was measured using four items (e.g., 'I will buy a product from Pantene.') on a 7-point Likert scale ranging from 1 = 'strongly disagree' to 7 = 'strongly agree' $(\alpha=.889, M=5.37, \mathrm{SD}=1.17$; van Reijmersdal et al. 2016).

Intention to disseminate (eWOM) was measured using two items (e.g., 'I could repost on my Instagram account the posts showed above.') on a 7-point Likert scale ranging from $1=$ 'strongly disagree' to $7=$ 'strongly agree' $\left(r_{s b}=0.807, M=4.00\right.$, $S D=1.69$; Sohn, 2009).

Table 1. Descriptive statistics per conditions

\begin{tabular}{lcccc}
\hline & \multicolumn{2}{c}{ "influencer" group } & \multicolumn{2}{c}{ "brand account" group } \\
\hline Variable & $\mathrm{M}$ & $\mathrm{SD}$ & $\mathrm{M}$ & $\mathrm{SD}$ \\
Brand Attitude & 6.03 & 0.939 & 4.80 & 1.65 \\
Purchase Intention & 5.52 & 1.130 & 5.23 & 1.19 \\
eWOM & 3.98 & 1.760 & 3.80 & 1.63 \\
\hline
\end{tabular}

\section{Data analysis and results}

Randomization was checked, $t$-tests were performed for age $p=.32$, for education $p=.575$ and for already following influencers $p=.52$ which are not significant, so the distribution by groups was random and does not influence the research results.

Brand recall was higher for the "influencer" group (97.5\%) compare to the "brand account” group (87.5\%). This is in line with H1. A series of $t$-tests performed in SPSS showed that there are significant differences in terms of brand attitude between the two groups: $p<0.001, t(1,78)=32,132$, but there are no significant differences between the two groups, for the purchase intention $p=.869$ and for the intention to disseminate $(\mathrm{eWOM}) p=.908$. Thus, hypothesis $\mathrm{H} 2$ is confirmed. The use of advertising through influencers leads to a positive attitude towards the brand.

Hypotheses $\mathrm{H} 3$ and $\mathrm{H} 4$ were not confirmed. There are no significant differences concerning the purchase intention of the participants who saw the advertising using influencers and the advertising on the Pantene brand account. No significant differences were observed also concerning the intention to disseminate between the two groups. 
One explanation in this regard is that the Romanian public is familiar with advertising through influencers, Pantene shampoo is a low involvement product, so that purchase intention is not influenced by influencer marketing. However, the descriptive statistic showed relatively high levels of purchase intention in the two groups ( $M=5.52$ for the "influencer" group and $M=5.23$ for the "brand account" group). When it comes to the intention to disseminate the results can be explained also by the low rates of reposts of Instagram in general, compared to other platforms such as Facebook or Twitter that have this feature among their standard menus.

\section{Conclusions, limitations, and implications of the study}

Following the experiment, we can conclude that choosing social media influencer advertising brings a plus to the brand both in terms of the user's attitude towards the brand and brand recall. Promoting a product through people known and admired by content consumers can add value to the brand. Promoting through social media does not involve many costs, it can be done either by offering a sum of money or barter and can be a plus of popularity for both parties involved, managing to increase the number of followers together.

The experiment has robust internal validity because it was conducted online, the stimulus being taken from the Instagram platform. In terms of external validity, the results cannot be generalized, due to the low number of 80 participants in our convenience sample. In everyday life, people watch a lot of posts on social media. Thus, they are subjects to multiple exposures. This is not the case of the present study that used a single exposure, that being a limit.

This study implies that social media influencer advertising is a recommended tool for brands as a substitute or in addition to the advertising of their social media brand accounts. It is important to choose an appropriate influencer in terms of matching with the brand.

The present research is interesting because it was performed with Romanian young consumers and by doing so it addresses a gap in the literature in advertising research. The paper contributes to a better understanding of the mechanism of social media influencer advertising. Future research with a complex experimental design and multiple exposures are aimed. It shows the potential of social media influencer advertising in a positive light that is in line with previous researches (Voorveld, 2019). 


\section{References}

1. Alhabash, S., Mundel, J. \& Hussain S.A. (2017). Social Media Advertising: Unraveling the Mystery Box. In Shelly Rodgers and Esther Thorson (eds.), Digital Advertising: Theory and Research (pp. 285-299). New York: Routledge.

2. Balaban, D.C. \& Mustatea, M. (2019). Users' Perspective on the Credibility of Social Media Influencers in Romania and Germany. Romanian fournal of Communication and Public Relations, 21(1), 31-46.

3. Boerman, S. C., van Reijmersdal, E. A., \& Neijens, P. C. (2014). Effects of Sponsorship Disclosure Timing on the Processing of Sponsored Content: A Study on the Effectiveness of European Disclosure Regulations. Psychology \& Marketing, 31(3), 214-224.

4. Boerman, S. C., \& van Reijmersdal, E. A. (2020). Disclosing Influencer Marketing on YouTube to Children: The Moderating Role of Para-Social Relationship. Frontiers in Psychology, 10, 30-42.

5. Campbell, C. \& Grimm, P. (2019). The Challenges Native Advertising Poses: Exploring Potential Federal Trade Commission Responses and Identifying Research Needs. fournal of Public Policy and Marketing, 38(1), 110-123.

6. Carpenter Childers, C., Lemon, L.L., \& Hoy, M.G. (2018). \#Sponsored \#Ad: Agency Perspective on Influencer Marketing Campaigns. Journal of Current Issues \& Research in Advertising.

7. De Veirman, M., Cauberghe, V. \& Hudders. L. (2017). Marketing through Instagram Influencers: The Impact of Number of Followers and Product Divergence on Brand Attitude, International fournal of Advertising, 36(5), 798-828.

8. Evans, J. N., Phua, J., Lim, J., \& Jun, H. (2017). Disclosing Instagram Influencer Advertising: The Effects of Disclosure Language on Advertising Recognition, Attitudes, and Behavioral Intent. Journal of Interactive Advertising, 17(2), 138-149.

9. Evans, Nathaniel J., Wojdynski, B. \& Grubbs Hoy, M. (2019). How Sponsorship Transparency Mitigates Negative Effects of Advertising Recognition, International fournal of Advertising, 38(3), 364-82.

10. Freberg, K., Graham, K., McGaughey, K., \& Freberg, L. A. (2011). Who are the social media influencers? A study of public perceptions of personality. Public Relations Review, 37(1), 90-92.

11. Friedstad, M., \& P. Wright. (1994). The Persuasion Knowledge Model: How People Cope with Persuasion Attempts. Journal of Consumer Research, 2, 1-31.

12. Janssen, L, \& Fransen, M. (2019). Written Honesty is the Best Policy: Effects of Disclosure Explicitness and Disclosure Modality on Brand Responses via Critical Attitudes. In Bigne, E., \& Rosengren, E. (ed.). Advanced in Advertising Research X. Multiple Touchpoints in Brand Communication (pp. 133-146), Wiesbaden: Springer Gabler.

13. Johnson, B., Potocki, B. \& Veldhuis, J. (2019). Is That My Friend or an Advert? The Effectiveness of Instagram Native Advertisements Posing as Social Posts. Fournal of Computer-Mediated Communication, 24(3),108-125.

14. Jung, A. R., \& Heo, J. (2019). Ad Disclosure vs. Ad Recognition: How Persuasion Knowledge Influences Native Advertising Evaluation. fournal of Interactive Advertising, 19(1), 1-14. 
15. Kaplan, A. M., \& Haenlein, M. (2010). Users of the World, Unite! The Challenges and Opportunities of Social Media. Business Horizons, 53(1), 59-68.

16. Katz, E., \& Lazarsfeld, P. (1955). Personal Influence: The Part Played by People in the Flow of Mass Communications. New York: The Free Press.

17. Liu, F. (2007). Constrained Opinion Leader Influence in an Electoral Campaign Season: Revisiting the Two-Step Flow Theory with Multi-Agent Simulation. Advances in Complex Systems. 10(2), 233-250.

18. Lou, C. \& Yuan, S. (2019). Influencer marketing: How message value and credibility affects consumer trust on branded content on social media. Fournal of Interactive Advertising, 91(1), 58-73.

19. Matthes, J., \& Naderer, B. (2015). Product Placement Disclosures: Exploring the Moderating Effect of Placement Frequency on Brand Responses via Persuasion Knowledge. Journal of Advertising: The Review of Marketing Communications, 35(2), 185-199.

20. McGuire, W. J. (1989). Theoretical Foundations of Campaigns. In R. E. Rice \& C. K. Atkins (Eds.). Public Communication Campaigns (pp. 43-65), $2^{\text {nd }}$ Edition. Newbury Park, CA: Sage Publications.

21. Mayrhofer, M., Matthes, J., Einwiller, S, \& Naderer, B. (2020). User-Generated Content presenting Brands on Social Media increases Young Adults' Purchase Intention. International. Journal of Advertising, 39(1), 166-186.

22. Nirschl, M. \& Steinberg, L. (2018), Einstieg in das Influencer Marketing. Grundlagen, Theorien und Erfolgsfaktoren. Wiesbaden: Springer Gabler.

23. Ohanian, R. (1990). Construction and validation of a scale to measure celebrity endorsers' perceived expertise, trustworthiness, and attractiveness. Fournal of Advertising, 19(3), 39-52.

24. Oprea, R. (2017). InfluenceMe report: 75 percent of internet users in Romania follow at least one online influencer, Romanian Business Review. Retrieved on June 2020, from https://business-review.eu/news/influenceme-report-75-percent-of-internet-users-inromania-follow-at-least-one-online-influencer-145921.

25. Statista (2019). Social Media Statistics and Facts. Retrived on June 2020, from https:// www.statista.com/statistics/272014/global-social-networks-ranked-by-number-of-users/.

26. Sohn, D. (2009). Disentangling the Effects of Social Network Density on Electronic Word-of-Mouth (eWOM) Intention. Journal of Computer-Mediated Communication, 14(2), 352-67.

27. Van Reijmersdal, A. E., Fransen, M. L., van Noort, G., Opree, S.J., Vandeberg, L., Reusch, S., Van Lieshout, F., \& Boermann, S. C. (2016). Effects of Disclosing Sponsored Content in Blogs: How the Use of Resistance Strategies Mediates Effects on Persuasion. American Behavioral Scientist, 60(12), 1458-1474.

28. Versamis, E. (2018). Are social media influencers the next-generation brand ambassadors? Forbes. Retrieved on June 2020, from https://www.forbes.com/sites/theyec/2018/ 06/13/are-social-media-\%09influencers-the-next-generation-brand-ambassadors/\#2 d8b9e82473d.\%0A.

29. Voorveld, H. (2019). Brand Communication in Social Media: A Research Agenda. fournal of Advertising, 48(1), 14-26. 


\section{Appendix}

\section{Stimulus materials}

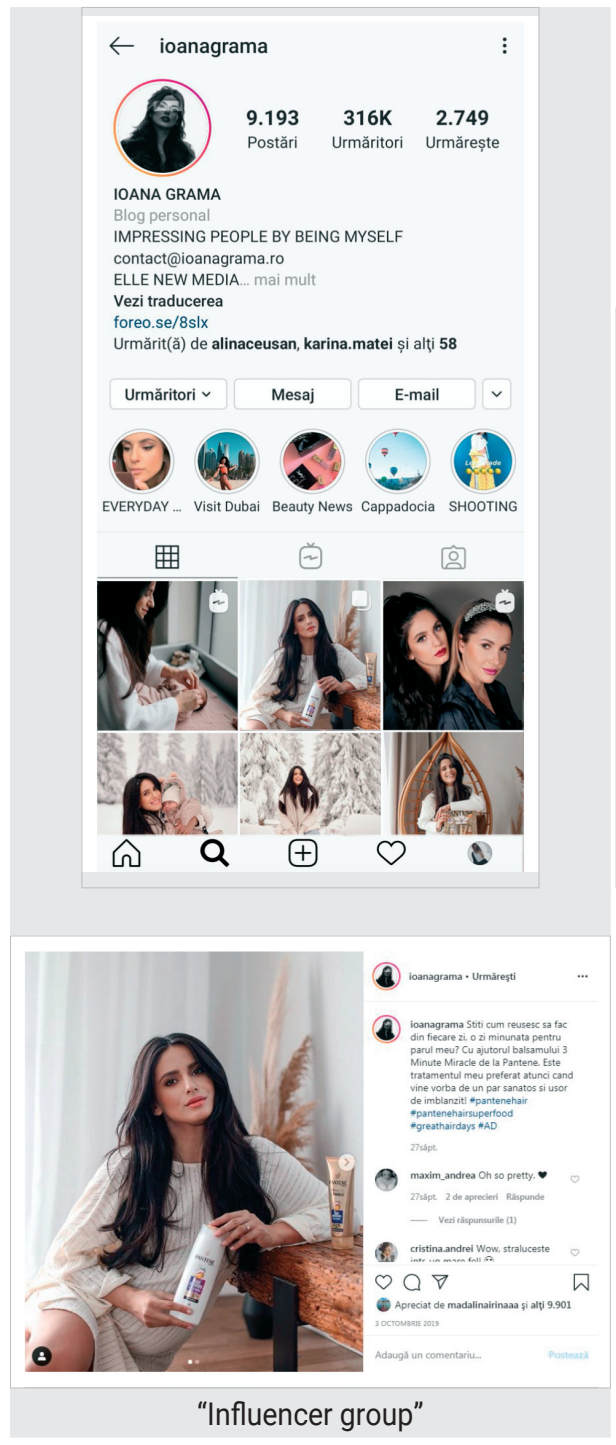

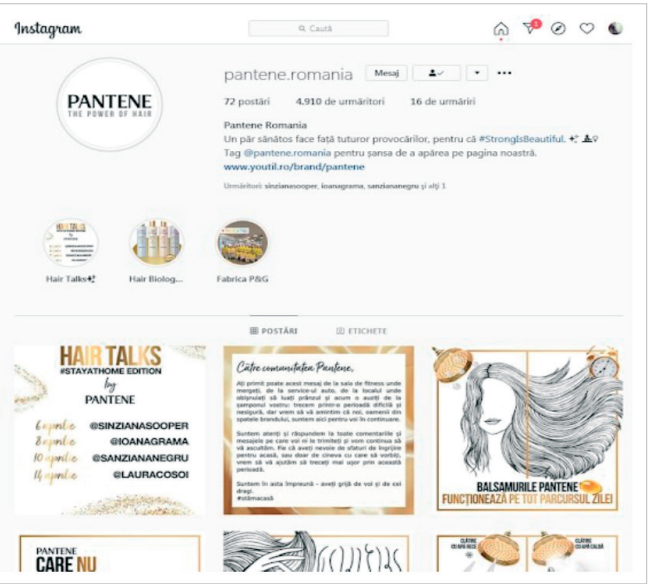

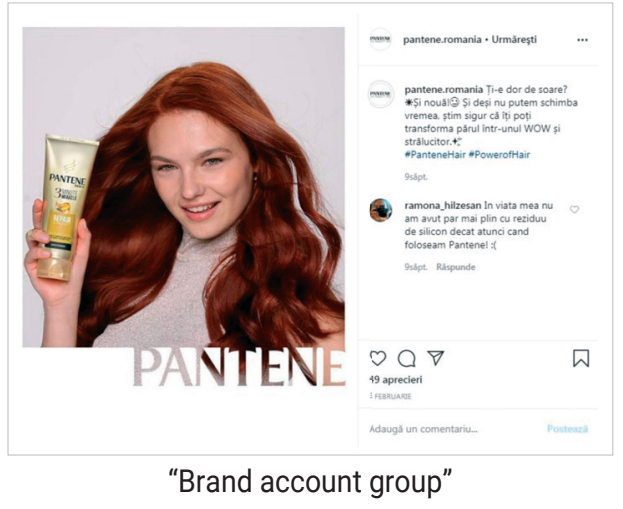

